\title{
STATE PROTECTION AGAINST ACTION OF \\ PERSECTION AND INTOLERANCE DURING THE COVID-19 PANDEMIC
}

\author{
Mulyati Pawennei ${ }^{1}$, Lisa Mery ${ }^{2}$, Syamsiar Arief ${ }^{3}$
}

Universitas Muslim Indonesia, Universitas Indonesia Timur

\begin{abstract}
The purpose of writing this article is to focus on how the Indonesian state in accordance with the Contitution, makes the protection of citizen' rights as one of the main characteristics of the implementation of human rights. In the process important issues that deserve to be studied in depth were discovered (1) the role of the state institutionally protecting citizens from acts of persecution and intolerance that also occurred during the Covid-19 pandemic; (2) prevention of acts of persecution and intoleranceaffecting the life of the nation and state in the past five years occurated in the Covid-19 pandemic. The results of the study provide a perspective that legal efforts which are a form of the existence of the practice of Pancasila and UUD 1945 including the implementation of protection of human rights in Law number 39/1999 concerning Human Rights as legal umbrella that must be upright and firm in its implementation, because law emforcement in human rights will fatale consequences with the destruction of diversity in the Republic of Indonesia, during the Covid-19 pandemic it turned out that persecution and intolerance continued and needed consistency in the protection of human rights law in accordance with the mandate of Pancasila as a value and UUD 1945 as a legal norm.
\end{abstract}

Keywords:

Human Rights, Persecution and Intolerance, Covid-19 Pandemic

\begin{abstract}
Abstrak
Tujuan penulisan artikel ini fokus pada bagaimana negara Indonesia yang sesuai Konstitusi menjadikan perlindungan hak warganegara sebagai salah satu ciri utama dari pelaksanaan hak asasi manusia. Dalam proses ditemukan masalah penting yang patut dikaji secara mendalam yaitu (1) Peran negara secara kelembagaan melindungi warganegara dari tindakan Persekusi dan Intoleransi yang terjadi pula selama pandemi Covid-19; (2) Pencegahan Tindakan Persekusi dan Intoleransi memengaruhi kehidupan berbangsa dan bernegara dalam kurun waktu lima tahun ini terjadi dalam pandemi Covid-19. Hasil penelitian memberikan perspektif bahwa upaya hukum yang merupakan wujud eksistensi amalan Pancasila dan UUD 1945 termasuk implementasi perlindungan Hak Asasi dalam UU No.39/1999 tentang Hak Asasi Manusia sebagai payung hukum yang
\end{abstract}


harus tegak dan tegas implementasinya, karena penegakan hukum dalam hak asasi manusia akan berakibat fatal dengan rusaknya keragaman dalam konteks hidup bersama dalam Negara Republik Indonesia, selama pandemi Covid-19 ternyata persekusi dan intoleransi tetap terjadi dan perlu konsistensi terhadap perlindungan hukum hak asasi manusia tersebut sesuai amanat Pancasila dan UUD 1945.

\section{Kata Kunci:}

Hak asasi manusia, Persekusi dan Intoleransi, Pandemi Covid-19

\section{A. PENDAHULUAN}

$\mathrm{I}$ ndonesia is a country that has a diversity of ethnicities, cultures, religions and social and economic life, for approximately 76 years of Indonesian independence there have been many lives that have tried to be organized into ideal or harmonius ways, people are accustomed to living together in tolerance and accepting each other's differences otherwise it is a gift to life together.

In essence with a greater understanding of diversity among individuals as citizens and the length of the process of living together with the people in Indonesia, which so far has been largely harmonious in the democratic process, especially law enforcement and protection of human rights should be easier, the phenomenon of guaranteeing human rights finds a negative turning point, when many information easily to accessible to each individual both on a small or local, national and international scale does not match the ability to behave and take wise action in individuals of one nation and country of different beliefs.

This presents a type of crime of persecution and intolerance that shrinks the space for the right to believe and embrace religion according to the first principle of Pancasila which reads "God Almighty", the substance of these principles is a philosophical and fundamental foundation in the diversity of life in Indonesia which is very heterogeneous.

The spread of persecution cases in Indonesia, beginning from the common thread of the case that befell Basuki Tjahaya Purnama or Ahok, who was the Governor of DKI Jakarta, after the case became a concern and ended with the conviction of the former Governor, the cases other persecution tends to increase. ${ }^{1}$ "Action of persecution and intolerance of the rights of fellow religious believers in Indonesia need to be minimized, even though in fact during the transition and consolidation period of democracy from the New Order Era to The Reformation Era, it went according to the corridors of democracy, so it deserves to be a concreate example for the religion and the country. In the Muslim world and Southeast Asia at that time, however, cases of persecution and religious intolerance continue to tarnish positive facts about democracy in Indonesia. It should be realized that intolerance develops in various forms of violence in the name of religion. The role of political 
actors who want power by operating means of coercion and hatred "hate crime". ${ }^{2}$

The act of vigilantism, accusing another person or group of people and then taking action to judge another party in the form of violence (chiding, beating, torturing, destroying the victim to kill) is against democracy, these actions have reviewed from various perspectives, including politics, socio-culture, religion, in this paper acts of persecution and intolerance will focus on being studied from the perspective of human rights law. The latest case, for example, of a veiled woman named Hesti Sutrisno, was persecution for raising dozens of stray dogs, this 'unpleasant' experience by animal lovers was carried out by animal lovers was carried out by a group on behalf of local residents in their refusal and invitation to ban Hesti from keeping dozens of wild dogs that she had rescued, a response from Chairman of PP Muhammadiyah (one of the largest mass organizations in Indonesia), Mr. Dadang Ahmad said that "from a good ethical point of view, a person loves animals including dogs because of God's creatures, and that is a good moral act. ${ }^{3}$

While discussing intolerance this is a big challenge for the Indonesian government because cases keep recurring, intolerance practices tend to have the same pattern since the early 2000s, cases such as closing places of worship. Minority group, the prohibition and dissolution of certain religious activities occurated in various regions of the Republic of Indonesia. The important points are still homework for the governmental, namely domestic law or policies that are not synchronized/contradictiory, for example there are rules that guarantee the right to freedom of religion or belief, but there are also rules and policies that can threaten freedom of religion and belief which are still maintained such as the PNPS Law Number 1 of 1965 concerning the Prevention of Religious Abuse/Defamation, the Joint Decree (SKB) of 3 Ministers of 2008 concerning Ahmadiyah, the Joint Ministers of Regulation (PBM) of 2 Ministers on Houses of Worship, as well as the existence of various regulations in the regions such as the Decree of the Governor, the Regent, Regional regulations or other SKB which limit freedom of religion or belief. Cases will continue to occur because the regulations are out of sync, and even become an instrument of the majority community group to legitimize action and practice of intolerance. According to Deputy Director of Imparsial Gufron Mabruri,"the lack of firmness and justice in enforcing the law against perpetrators of intolerance and protection for victims exacerbates this condition." 4

It takes legal and policy reforms that are based on human rights values more seriously. Therefore, in the discussion, there are two important questions to discuss from the perspective of law enforcement and protection of human rights, the formulations of these problems include :

\footnotetext{
${ }^{2}$ Munandzirul Amin pada Jurnal Madani, tahun 2020, p. 89

${ }^{3}$ https://nasional.okezone.com/read/2021/103/16/337/2378700/pelihara-anjing-wanita-bercadardipersekusi-simak-selengkapnya .. access on tuesday, 23 Maret 2021.

${ }^{4}$ Source : https://kompas.com "Imparsial : Intoleransi Masih Jadi Masalah yang Terus Berulang di Indonesia”, access on tuesday, 23 Maret 2021
} 
1. How can the state institutionally protect citizens from persecution and intolerance during the Covid-19 pandemic?

2. How has the prevention of persecution and intolerance increasingly affected the life of the nation and state in the last 5 years, especially during the Covid-19 era?

The tendency of increasing forms of actions by perpetrators in relation to persecution and intolerance, both carried out directly through vigilante acts of eigenrichting (threats, assault and beatings) and indirect action through social media by posting hate speech, invitations to gang up and verbal threats. Taking human rights in personal and social life, worrying and spreading fear are important to analyze and provide meaningdul input for upholding and protecting human rights, especially during the Covid-19 pandemic which has increasingly made personal friction between citizens, various forms. The cases and issues reviewed indicate the broad spectrum of studies that must be relugalet in the enforcement of human rights law.

\section{B. METODE PENELITIAN}

This research is normative legal research. Data analysis in research was carried out with a qualitative approach, taking data from various literatures where data presentation was carried out by analyzing legal events or relevant cases, appropriate books and journal and credible news media. Through the research process, the analysis and construction of the data collected and processed will be carried out. ${ }^{5}$

\section{RESULT \& DISCUSSION}

Persecution is a noun, taken from English (n) persecution : French; Latin persecute. The Oxford Dictionary, English defines the word persecution (n) as hostility and ill treatment, especially because of race or political or religious belief; oppression. The verb persecute (v) is defined as Subject (someone) to hostility and illtreatment, especially because of their race or political or religious beliefs. Merriam Webster's dictionary defines persecution (n) as the act or practice of persecuting especially those who differ in origin, religion, or social outlook. Meanwhile, persecute (v) to harass or punish in a manner designed to injure, grieve, or afflict specifically to cause to suffer because of belief. ${ }^{6}$

Persecution in international law is an act of crimes against humanity in various international legal documents, implicitly stated in the Convention on the Prevention and Punishment of the Crime of Genocide of 1948 Article 2 which states that what is called genocide is an act with the intention of destroying, in whole or in part, a group religion, race, ethnicity or nationality by (a) killing, (b) physically or mentally damaging,(c) physical destruction, (d) preventing birth, $€$ transferring children from

\footnotetext{
${ }^{5}$ Soerjono Soekanto dan Sri Mamudji, Penelitian Hukum Normatif, Suatu Tinjauan Singkat,Jakarta : RajaGrafindo Persada,2014), p.1

${ }^{6}$ Source : https:www.merriam-webster.com/persecute. Access on ; 23 maret 2021

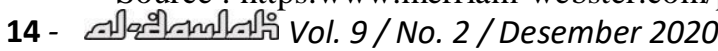


one group to another. ${ }^{7}$

Persecution is defined as "arbitrary hunting of a person or a number of citizens and being hurt, distracted or crushed. ${ }^{8}$ From these various definitions the conclusion is that persecution is a non-singular crime, the crime of persecution can arise from various forms, starting with ill-treatment, intimidation, persecution and even murder with differences in race, politics and religion or belief. The key to Indonesia remaining harmonius in adhering to different beliefs and religions in the life of the nation and state is that fellow religious communities avoid arrogance, oppression, bend and want to win by themselves, subjective opinions than others are infidels, deviants and must be destroyed cannot continue to be given place and space for developing, this will trigger divisions between the Ummah as happened in the Middle East, and European countries or other regions in the world. There are two components to focus on the level of intolenrance in Indonesia, namely tolerance and inclusion, subcomponents of tolerance, namely tolerance for immigrants, tolerance from discrimination and violence against minorities, religious tolerance, and community security networks. To map the potential violations committed in caes of persecution and intolerance in Indonesia, a classification of the subjects who committed the violation was carried out, both by state actors and non-state actors.

\begin{tabular}{|c|c|c|c|}
\hline No. & $\begin{array}{c}\text { Category of } \\
\text { Offender } \\
\text { (subject) }\end{array}$ & Type of Action & Description \\
\hline 1. & State Actor & $\begin{array}{l}\text { 1. Local Government human rights } \\
\text { violation ( } 157 \text { actions) } \\
\text { 2. Police Institutions ( } 98 \text { actions) } \\
\text { 3. Education Institution ( } 35 \text { actions) } \\
\text { 4. Pamong Praja Police Unit ( } 33 \text { actions) } \\
\text { 5. Court (18 actions) } \\
\text { 6. Attorney Office (17 actions) } \\
\text { 7. TNI (11 actions) } \\
\text { 8. Ministry of Civil Service (14 actions), } \\
\text { 9. Village Administration (5 actions) }\end{array}$ & $\begin{array}{l}\text { Among others, } \\
\text { violation of human } \\
\text { rights discrimination, } \\
\text { hate speech, etc. }\end{array}$ \\
\hline
\end{tabular}

2021.

${ }^{7}$ Source : https:www.un.org/en/genocideprevention/genocide-convention.shtml access on Selasa, 23 Maret

${ }^{8}$ kbbi.web.id access on 22 Maret 2021 


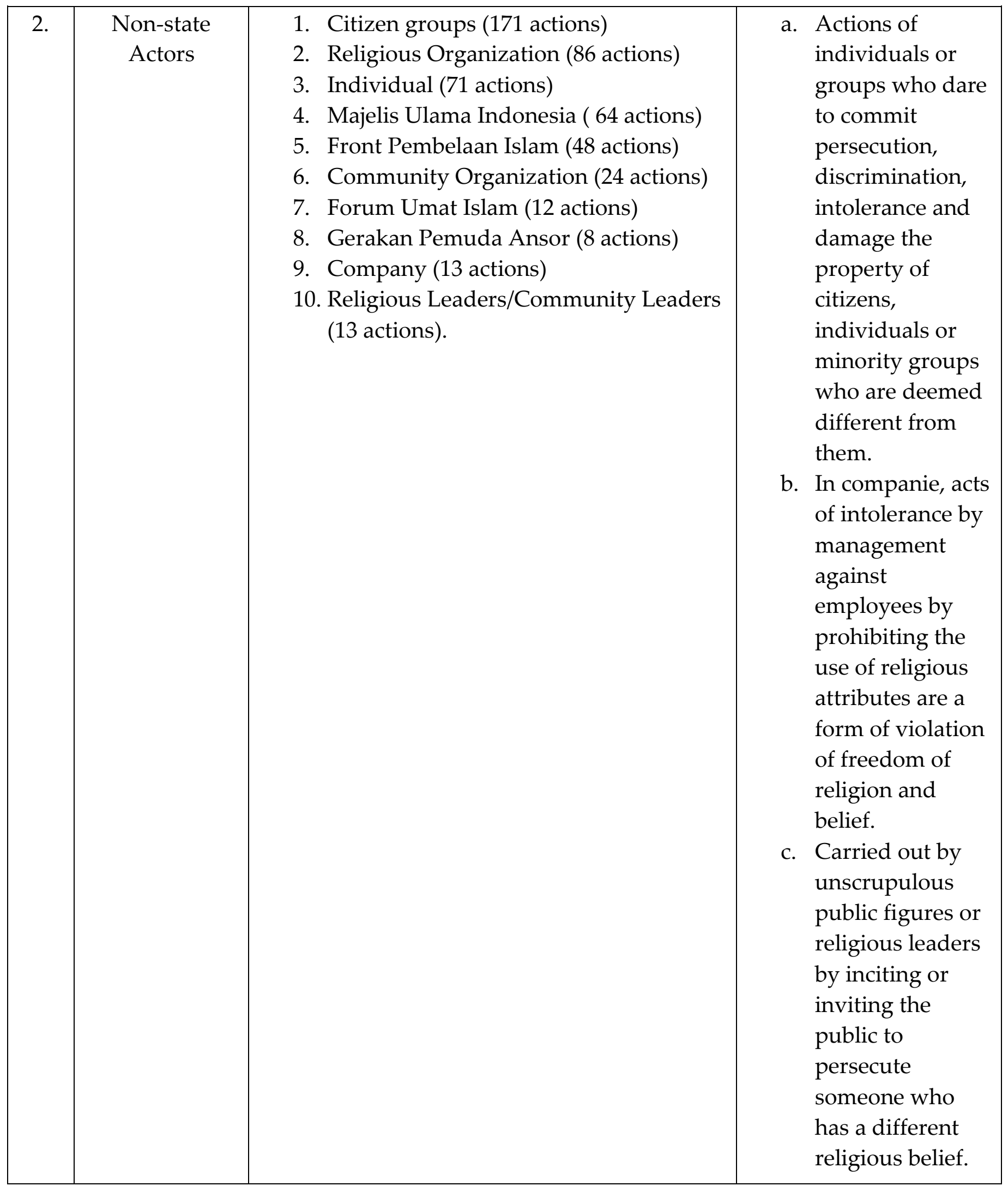

Table 1

Classification of perpetrators of Persecution and Intolerance ${ }^{9}$

${ }^{9}$ Source : https://tirto.id/cEPz?utm_source "Ibukota RI, DKI Jakarta ....access on Tuesday, 23 Maret 2021 


\section{The Role of The State Institutionally to Protect Citizens From Persecution and Intolerance in Particular During The Covid-19 Pandemic.}

Persecution and intolerance cases occur because of the exclusivity of certain groups, one of which is the presence of the takfiri movement, deviance and disbelief which leads to acts of persecution and intolerance which are forms of theological violence followed by forms of physical violence.

Efforts to respect and protect and uphold human rights are shared obligations and responsibilities between individual, the government and the state, therefore the fulfillment, protection and respect for human rights are in line with human obligations in this common life. Human rights instruments in Indonesia can be found in the 1945 Constitution Article 28 A as the legitimacy of the birth of law Number 39 of 1999 concerning Human Rights and Law Number 26 of 2000 concerning Human Rights Cours, etc. The establishment of National Human Rights Commission is also part of respecting, protecting and maintaining the existence of human rights consistently in the country of Indonesia.

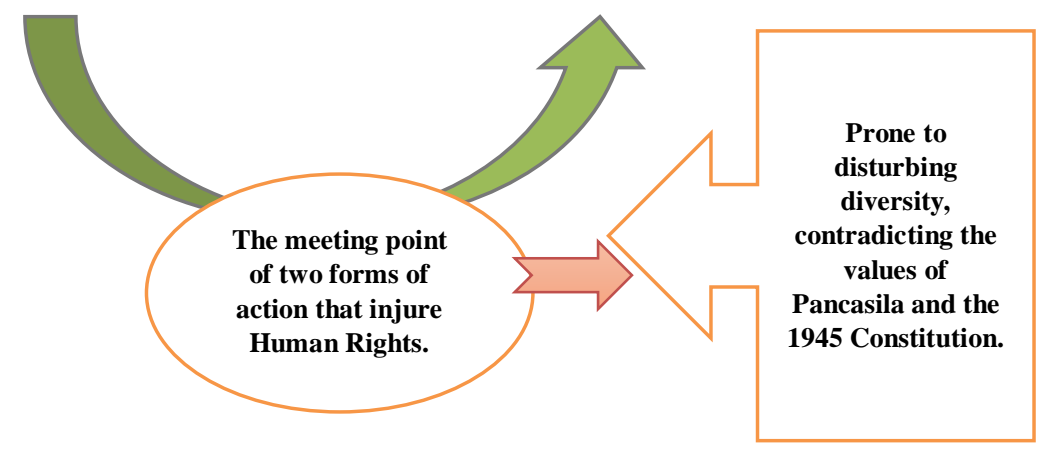

Figure 1 : Describes the elements of Persecution and Intolerance

The elements described in the image or illustration above are explanation that there is a pattern of close relationships in the issue of violations of individual or group rights in the last few years, the initial momentum is more at beginning of massive acts of persecution and intolerance of recurring events since 2017.

The theory of Prof. David Cohen gives two emphases to determine the presence or absence of persecution with two level of evidence, first, the contextual element or persecution, namely the knowledge of the perpetrator that his actions were part of a systematic or widespread attack against the civilian population. Second, there are grounds for discriminating against victims, groups or collectivities to which they are a part: poltics (not necessarily institutionalized), race, nationalty, ethnicity, culture, religion, gender or other grounds that are universally prohibited under international law. ${ }^{10}$ The perpertrator of the persecution can be anyone, not only government or state organs, but also civil society. Persecution has reached the stage of threatening freedom of speech and democracy, because a group of people can determine

${ }^{10}$ Source : https://ylbhi..or.id/informasi/kegiatan/persekusi-dalam-kerangka-hukum-internasional/ access on Tuesday, 23 Maret 2021 
someone guilty and punish without going through the legal process.

Meanwhile, on intolerance in Indonesia, on 2018 data by researchers from The Indonesian Institute of Science (LIPI) from 1.800 repondents aged 17-64 years old, in nine provinces in Indonesia it was found that factors that directly influence intolerant behavior include religious fanaticism, distrust or religions and other ethnicities, secularism, feelings of being threatened and social media. UPI's Reseach in 2018 shows that suspicion of parties with differnts beliefs contributes to the growth of intolerance, research respondents have the opinion that people with different beliefs or religions cannot be trusted and tend to exploit other parties when theya have power, besides LIPI data provides an overview of respondents who feel threatened whwn people of different religions become important officials and have power in the economic and political sectors.

During the Covid-19 pandemic it should have made people more solidarity, but incidents of persecution and acts of intolerance in Indonesia, cases of human rights violation that occurated among others were also forms of violations committed by educational institutions including discrimination, disrurbances to places of workship which can be documemented from period of President Joko Widodo as many as 51 disturbance, most of which occurred in Churches. ${ }^{11}$

Two months after the Covid-19 pandemic was declared to have entered Indonesia, there were cases of persecution of residents who performed worship at home, by other residents, acts of forced breakthroughs, freedom of worship and discrimination against the rights of followers of other religions that contradict the values of Pancasila and norms a law in the 1945 Constitution.

The regulations related to the act of persecution do not explicitly regulate and specifically have a legal umbrella to protect the Indonesian people, this makes law enforcement officials unable to be immediately enlightened in choosing legal sanctions for an act of persecution. The concept of persecution can be interpreted as a framework or design and/or to find out the concept of persecution itself against positive legal rules, according to the hierarchy of the prevailing laws and regulations, the closest study to the category of acts of persecution starting from the 1945 Constitution, Law of the Republic of Indonesia Number 39 of 1999 concerning Human Rights and the Criminal Code. The study accoding to Law Number 39 of 1999 on Human Rights is not much different from the 1945 Constitution, the focus of Article 1 is on General Provisions or more precisely on points 4 and 5, namely regarding torture and human rights violations, the description or concept that persecution is included in ordinary human rights violations.

Meanwhile in the Criminal Code, the act of persecution is defined as a criminal act that equates persecution with one of the forms of crime contained in the Criminal Code, namely Article 170 of the Criminal Code concerning Beatings and in the Criminal Code Book II on Crimes in Chapter XX concerning Persecution starting from Articles 351-358 of the Criminal Code, which defines persecution as a criminal

${ }^{11}$ Source : https://akurat.com "Rata-rata Setiap Bulan Terjadi 14 Pelanggaran Kebebasan Beragama" access on a 23 Maret 2021

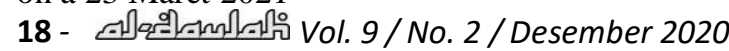


act that is categorized as a crime. In the Criminal Code, the act of persecution is part of the form of crime, in this case the reference or variable, namely from the meaning and elements of persecution itself. ${ }^{12}$

In an event several violations may occur, the following table is a concrete illustration to clarify an indication of the situation that occurs in acts of persecution and intolerance in Indonesia :

\begin{tabular}{|c|c|c|c|c|}
\hline Number & $\begin{array}{c}\text { Form/types of acts of } \\
\text { persecution and } \\
\text { intolerance }\end{array}$ & $\begin{array}{l}\text { Type of rights } \\
\text { being violated }\end{array}$ & $\begin{array}{c}\text { Articles that } \\
\text { are violated }\end{array}$ & Cases/events \\
\hline 1. & $\begin{array}{l}\text { Threat of violence/use of } \\
\text { violence by government } \\
\text { officials. }\end{array}$ & $\begin{array}{l}\text { Freedom of } \\
\text { association. }\end{array}$ & $\begin{array}{l}\text { Article } 28 \text { E } \\
\text { UUD } 1945\end{array}$ & $\begin{array}{l}\text { The KONTRAS report } \\
\text { noted that between } \\
2015-2018 \text { there were } \\
1.056 \text { cases of peaceful } \\
\text { assembly, the } \\
\text { involvement of state } \\
\text { officials in violations } \\
\text { of restrictions on the } \\
\text { rights to freedom of } \\
\text { assembly, either } \\
\text { directly or indirectly } \\
\text { with a pattern of } \\
\text { neglect, this is because } \\
\text { the interpretation of } \\
\text { legislation carried out } \\
\text { by the authorities is } \\
\text { very broad so that } \\
\text { there is alack of } \\
\text { understanding. These } \\
\text { officers have an impact } \\
\text { on not being } \\
\text { responsive to sensitive } \\
\text { issues.. }\end{array}$ \\
\hline 2. & $\begin{array}{l}\text { Threat of violence/use of } \\
\text { violence by the } \\
\text { community. }\end{array}$ & $\begin{array}{l}\text { Freedom of } \\
\text { Speech and } \\
\text { Expression. }\end{array}$ & $\begin{array}{c}\text { Article } 28 \\
\text { Paragraph (2) } \\
\text { UU ITE or } \\
\text { Article } 156 \text { a } \\
\text { KUHP. }\end{array}$ & $\begin{array}{l}\text { In June } 2017 \text {, the Anti- } \\
\text { Persecution Coalition } \\
\text { recorded the } \\
\text { persecution of } 59 \\
\text { peoples who were } \\
\text { labeled as } \\
\text { blasphemers/clerics, }\end{array}$ \\
\hline
\end{tabular}

${ }^{12}$ I Made Arif Dwi Cahyadi, I Gusti Bagus Suryawan dan I Nyoman Sutama,2019, "Penegakan Hukum Terhadap Adanya Aksi Persekusi,” Jurnal Analogi Hukum, Vol. 1 No.2, hlm. 218-222. 


\begin{tabular}{|c|c|c|c|c|}
\hline & & & & $\begin{array}{l}\text { individuals suspected } \\
\text { of having previously } \\
\text { been followed by } \\
\text { digital traces because } \\
\text { they were deemed to } \\
\text { have insulted religion } \\
\text { and clerics, then the } \\
\text { victim's identity in the } \\
\text { form of photo and } \\
\text { office address and } \\
\text { even a home address } \\
\text { was disseminated with } \\
\text { a tone of hatred and } \\
\text { instructions for these } \\
\text { people to be hunted } \\
\text { down. }\end{array}$ \\
\hline 3. & $\begin{array}{l}\text { Threats/use of violence } \\
\text { by elements of } \\
\text { government officials. }\end{array}$ & $\begin{array}{l}\text { Freedom of } \\
\text { speech. }\end{array}$ & $\begin{array}{l}\text { Article } 28 \mathrm{E} \\
\text { UUD } 1945 \\
\text { Article } 28 \mathrm{~F} \\
\text { and Article } 14 \\
\text { Law Number } \\
39 \text { of } 1999 \\
\text { concerning } \\
\text { Human } \\
\text { Rights. }\end{array}$ & $\begin{array}{l}\text { The case of Pandu } \\
\text { Riono an } \\
\text { epidemiologist from } \\
\text { Indonesian University, } \\
\text { whose social media } \\
\text { account was hacked ny } \\
\text { an unknown party in } \\
\text { August 2020, Pandu } \\
\text { often criticized } \\
\text { government policies } \\
\text { and regulations } \\
\text { regarding the handling } \\
\text { of the Covid-19 } \\
\text { pandemic involving } \\
\text { security actors. }\end{array}$ \\
\hline 4. & $\begin{array}{l}\text { Threats/use of violence } \\
\text { by social organizations. }\end{array}$ & $\begin{array}{l}\text { Freedom of } \\
\text { speech. }\end{array}$ & $\begin{array}{l}\text { Article } 28 \text { E } \\
\text { UUD } 1945\end{array}$ & $\begin{array}{l}\text { Violations in the form } \\
\text { of intimidation, } \\
\text { prohibition, } \\
\text { vandalism, } \\
\text { interrogation, arrest, } \\
\text { banning and forced } \\
\text { dispersal were carried } \\
\text { out by community } \\
\text { organizations in the } \\
\text { 2015-2018 period } 65\end{array}$ \\
\hline
\end{tabular}




\begin{tabular}{|c|c|c|c|c|}
\hline & & & & $\begin{array}{l}\text { times, } 32 \text { times by } \\
\text { mass organizations } \\
\text { namely FPI, PUI, GPK, } \\
\text { NU Banser, GP Ansor, } \\
\text { Pemuda Pancasila, } \\
\text { FKPPI. }\end{array}$ \\
\hline 5. & $\begin{array}{l}\text { Threats/use of violence } \\
\text { by individuals or } \\
\text { community } \\
\text { organizations }\end{array}$ & $\begin{array}{c}\text { Differences in } \\
\text { political or } \\
\text { minoriry views. }\end{array}$ & $\begin{array}{c}\text { Articles } 28 \text { E } \\
\text { Paragraph (3) }\end{array}$ & $\begin{array}{l}\text { On April 29, } 2018 \text { there } \\
\text { was intimidation by a } \\
\text { group of people } \\
\text { wearing the shirt } \\
\text { \#2019gantipresiden on } \\
\text { a car free day at the } \\
\text { Indonesian hotel } \\
\text { roundbout, Jakarta to a } \\
\text { resident on behalf of } \\
\text { Susi Ferawati and her } \\
\text { child. }\end{array}$ \\
\hline 6. & Threats or use of force & $\begin{array}{l}\text { Prohibition of } \\
\text { religion for } \\
\text { minorities }\end{array}$ & $\begin{array}{c}\text { Article } 29 \\
\text { Paragraph (2) }\end{array}$ & $\begin{array}{l}\text { The case of } \\
\text { Ahmadiyya } \\
\text { congregation being } \\
\text { banned from } \\
\text { worshipping at the } \mathrm{Al} \\
\text { Hidayah Mosque in } \\
\text { Depok, West Java } \\
\text { which is the } \\
\text { community mosque, } \\
\text { the same thing also } \\
\text { happened in the form } \\
\text { of a ban on worship } \\
\text { and the expulsion of } \\
\text { Shi'a congregation in } \\
\text { Sampang Madura . }\end{array}$ \\
\hline
\end{tabular}

Table 2

\section{Action Form from Persecution \& Intolerance}

The review in the data contained in the table shown in this study requires many supporting indicators, as an overview, the illustration in the table is an illustration of phenomenon that urges attention in terms of upholding the rule of law and protecting human rights in a democratic climate in Indonesia.

2. Prevention and Handling of Persecution and Intolerance Specifically during The Covid-19 Pandemic.

Law enforcement against perpetrators of persecution and intolerance in 
Indonesia differs in the level of execution in the field or reality according to the context of the events and the severity of the actions that occur, the practice of intimidation and violence committed by certain individuals and grous, such as the law of the jugle, this is a real threat, which continues over the years occurs and disturbs, even disturbs the rule of law, in the perspective of the Constitution Article 28 A to 28 J UUD 1945 which regulates constitutionally the guarantee of protection and security of every citizen from various kinds of threats.

Everyone has the right to live, not to be tortured and no one can lose the life of another human being for any reason. Everyone also has the right to personal and family protection and the right to a sense of security and protection from the threat of fear to do or not do something that constitutes a human right, "whoever seizes the individual's rights is subject to punishment in accordance with the applicable law.

To minimize acts of persecution and intolerance, especially in the vulnerable period of the Covid-19 pandemic, two solution approaches can be made, including the inter-religious relation approach and the legal approach, first, method may be carried out periodically with socialization, narrative of tolerance through mass communication and online media, sociological closeness culture among people in Indonesia can certainly be preserved as long as interpersonal narratives are still in the corridor or mutual respect. There are two parts to the legal approach to criminal cases in terms of objectives. ${ }^{13}$ First is criminal as punishment and the imposition of criminal sanctions against people who violate the criminal law. It should be noted that between persecution and "vigilante action" there are certain conditions that make vigilante actions not punishable because there are "reasons for the abolition of the crime" ${ }^{14}$

The act of persecution can be identified as "vigilante action" which almost always runs parallel to the violation of the rights of others, and therefore it is prohibited that act indicates there is an indication of low awareness of the law. ${ }^{15}$ "If it is elaborated that when the vigilante act occurs in which the context is almost the same as persecution, it can be ascertained there are other human rights that are deprived, according to the constitutional rules the right to enter is part of protection and law enforcement when there are strong indications of violations, as well as other problems related to the low level of awareness of the law so that it should be, between normative legal rules with people's understanding of prudence in acting in the community are very important and crucial to continue to be socialized, the role must be continuously carried out by the central government to the regions, the community either individually or in groups so that the type of mop this budget is not sustainable and difficult to control.

Action of persecution and intolerance in Indonesia as a contry with a Muslim majority population, are still quite high indications of tensions among religious adherents, even though tolerance is basically a good thing, empirically recorded acts

\footnotetext{
${ }^{13}$ Teguh Prasetyo, 2010, Hukum Pidana, Jilid II, Jakarta, Rajawali Press, p. 7

${ }^{14}$ Nur Pujayanti, Harry Soeskandi, Jurnal Mimbar Keadilan, Volume 14 No.28, p. 245

15 Andi Hamzah, 1986, Kamus Hukum, Jakarta, Ghalia Indonesia, p. 167

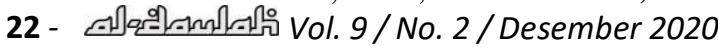


of persecution and religious intolerance exist and are localized, the reform era that guarantees freedom of information causes the phenomenon of relations between religious adherents to experience a point of vulnerability due to sectarian conflict that are used by individuals, groups of people and their spread interests and seek profit from friction in society.

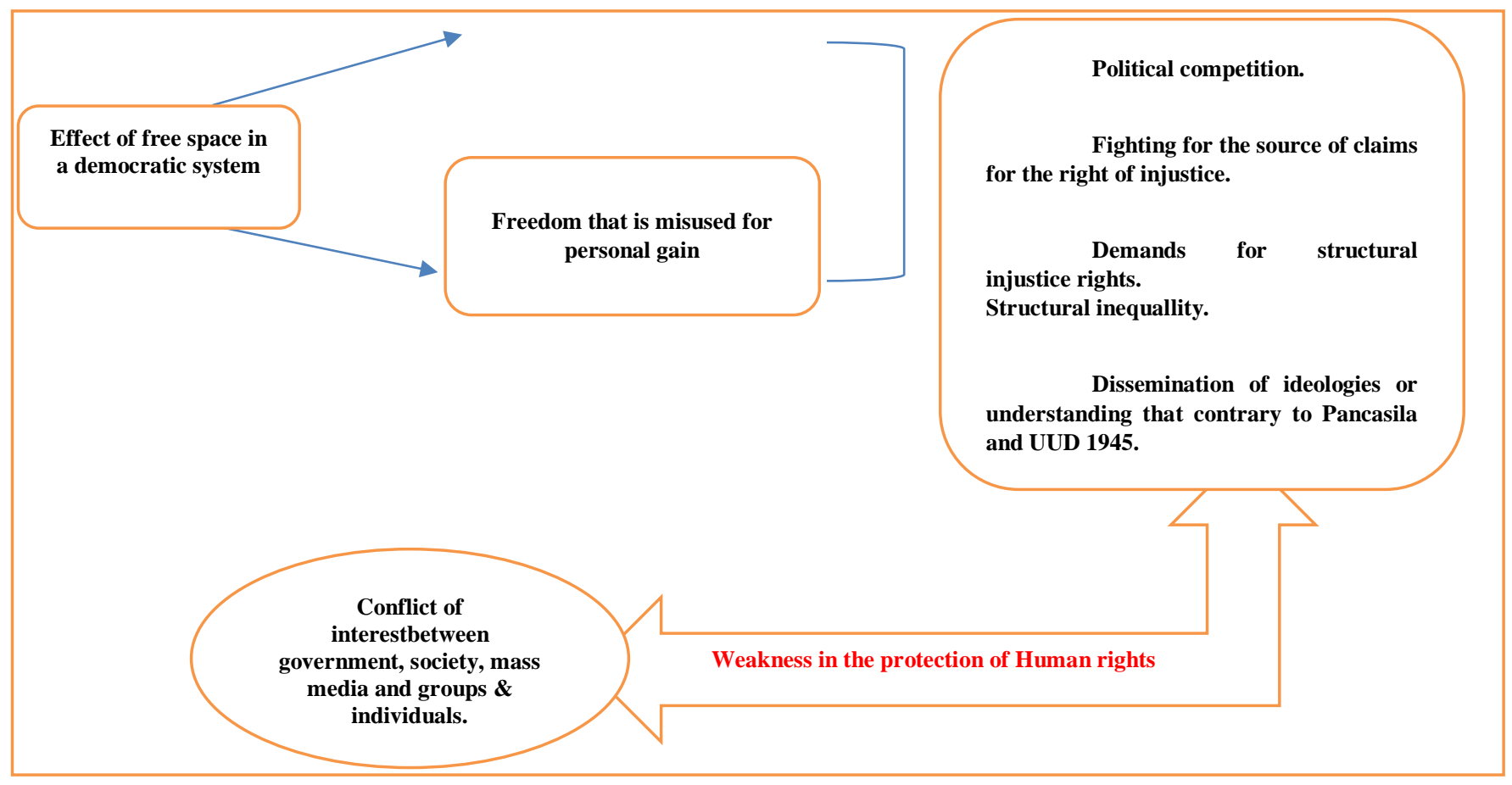

\section{Description of the reality of the effect transition on acts of persecution and intolerance in Indonesia}

The approach to relation between religious communities and the legal approach really needs to be done systematically, not only when an event or act of persecution and intolerance is spreading, but continuously in the context of establishing diversity that is vulnerable to being exposed to radicalism, especially during the Covid-19 pandemic, people's become more sensitive, the level of health is more susceptible to explosure to the virus and the mass media continues to inform various things that, if consumed by the general public without critical thinking about news sources, news substance and the ability to reason on the interpersonal benefits of relationships in life together, the possibility of acts of persecution and intolerance grows more massive and injuring the harmonious togetherness pattern in the context of human 
rights.

\section{CONCLUSION}

For a long time, cases of persecution and intolerance in Indonesia have been handled by the government with preventive measures alone, many violations require serious handling, because the role of the Indonesian govermentt has a broader scope and systematic authority from the central level to the regions, the NRI government. It can not only open up discourse but be involved in overcoming, minimizing and even taking control in aligning the fragility of the frame to Indonesia, which continues to be plagued by sensitive after the reformation and the increasingly blurred boundaries between countries. The involvement of individuals, religious organizations, community organization, legal leaders and experts and the government will be able to accelerate programs to eliminate new seeds of violence from acts of persecution and intolerance in the Republic of Indonesia, it necessary to pay attention that any omission will have a greater impact in the future.

Legal measures that are a manifestation of the existence of the Pancasila practice and UUD 1945, including the implementation of protection of Human Rights based on Law number 39 of 1999, under the law that must be upright and firm in its implementation, do not let carelessness end fatally with destruction of diversity in the context of living together in the State.

\section{References}

Hamzah, Andi. 1986, Kamus Hukum, Jakarta, Ghalia Indonesia, hlm. 167

Ardipandanto, Aryojati. "Persekusi : Perspektif Demokrasi," Majalah Info Singkat, Vol. IX, No. 11/I/Puslit/Juni 2017.

Cahyadi, I Made Arif. Suryawan, I Gusti Bagus. Sutama, I Nyoman. 2019, "Penegakan Hukum Terhadap Adanya Aksi Persekusi," Jurnal Analogi Hukum, Vol. 1 No.2.

Amin, Munandzirul. "Merebaknya Intoleransi (Hate Speech and Hate Crime) dalam politik Indonesia," Jurnal Madani, Vol. 12 No.1 Februari 2020.

Pujayanti. Soeskandi, Harry. Jurnal Mimbar Keadilan, Volume 14 No.28,hlm. 245

Soekanto, Soerjono. Mamudji, Sri. "Penelitian Hukum Normatif, Suatu Tinjauan Singkat,"Jakarta : RajaGrafindo Persada,2014).

Prasetyo, Teguh. 2010, Hukum Pidana, Jilid II, Jakarta, Rajawali Press.

https://nasional.okezone.com/read/2021/103/16/337/2378700/pelihara-anjing-wanita-

bercadar-dipersekusi-simak-selengkapnya.. Diakses pada Selasa, 23 Maret 2021. https://kompas.com “Imparsial : Intoleransi Masih Jadi Masalah yang Terus Berulang di Indonesia", diakses pada Selasa, 23 Maret 2021.

https:www.merriam-webster.com/persecute. Diakses pada tangga; 23 maret 2021. https:www.un.org/en/genocideprevention/genocide-convention.shtml diakses pada Selasa, 23 Maret 2021. 
https://irto.id/cEPz?utm_source “Ibukota RI, DKI Jakarta ... diakses pada Selasa, 23 Maret 2021.

https://ylbhi..or.id/informasi/kegiatan/persekusi-dalam-kerangka-hukuminternasional/ diakses pada Selasa, 23 Maret 2021. 